日本水処理生物学会誌

Jap. J. Water Treat. Biol., Vol.28. No.2, 1992

\title{
養魚池から分離したScenedesmus acutusの増殖特性
}

\section{Growth characteristics of Scenedesmus acutus isolated from fish pond.}

\author{
小橋二夫 ${ }^{1)} \cdot$ 出口吉昭 ${ }^{1)} \cdot$ 東 禎三 $^{1)} \cdot$ 矢崎仁也 ${ }^{1)} \cdot$ 矢木修身 ${ }^{2)}$ \\ Tsugio KOBASHI ${ }^{1)} \cdot$ Yoshiaki DEGUCHI $^{1)} \cdot$ Teizoh HIGASHI $^{1)} \cdot$ Jinya YAZAKI $^{1)}$ \\ Osami YAGI ${ }^{2}$
}

日本大学農獣医学部1) - 国立環境研究所 ${ }^{2)}$

College of Agriculture and Veterinary Medicine,Nihon Univresity ${ }^{1)}$. The National Institute for Environmental Studies ${ }^{2)}$

\begin{abstract}
Growth characteristics of Scenedesmus acutus isolated from fish culture pond were investigated in various nutrient concentrations.

Cultivations were carried out at $25-30^{\circ} \mathrm{C}$ in continuous ligth illumination with cool-white fluorecent lamps at 3,000lx.

Maximum growth was obtained at an initial $\mathrm{pH}$ value of 7.0 in Gorham's medium and 9.0 in modified Gorham's medium.

Nitrogen souces used urea, ammonium,nitrite and nitrate were significantly effective for the growth of $S$. acutus. Final $\mathrm{pH}$ value at ammonium were 4.1 or $9.0-10.0$ at the other nitrogen. A good growth was obtained at concentration of $14 \mathrm{mg} / \mathrm{l}$ for nitrogen and $62 \mathrm{mg} / \mathrm{l}$ for phosphorus.
\end{abstract}

\section{1. はじめに}

わが国の養魚は養魚形態によって、止水式、流水式お よび循環滤過式養魚に大別され、そのほとんどが集的的 な給餌養魚である。このような養魚では魚、池水および 底泥等によって消費される酸素の補給、給餌に伴って生 ずる多量の排せつ物および残餌の処理いかんによって、 魚の生産量が左右される。

近年わが国の水資源もひっ迫し、再利用の方向にあ り、水産用水としての水资源も制約されつつある。そこ で古くからウナギやコイ等の養殖に用いられ、盖殖期間
中ほとんど池水の交換が行われない、止水式養魚を再検 討する必要があると考える。

止水式養魚において、酸素補給は植物プランクトン、 大気からの溶入、注水等で、植物プランクトン由来が

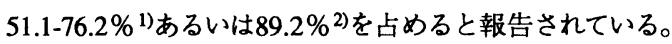
また酸素消費は魚類、飼育水、池底泥、大気への放出 等て、飼育水と池底泥による酸素消費量は46.9-59.4\% ${ }^{1)}$ ないし $83.7 \%{ }^{2)}$ であると報告されている。植物プランクト ンは無機化された物質を栄養塩として増殖し、ひいては 光合成作用により水中に酸素を補給している。

山形と丹羽はウナギを用い、アンモニアの急性毒性と 慢性毒性について報告し、急性毒性はpH7で24h-LD50が $863 \mathrm{mg} / \ell 、 \mathrm{pH} 9$ で同じく $16.8 \mathrm{mg} / \ell$ であり、 pHが高いほ どアンモニアの濃度が低く、毒性が高くなる。これはア ンモニアの解離が $\mathrm{pH}$ と温度により影響される。魚類に顕 著な毒性を与えるのが非解離のアンモニアで、非解離の アンモニアが $0.067 \mathrm{mg} / \ell$ 以上でウナギの成長量が半滅す る。またpH6.8で9週間の慢性毒性では20-40mg/ $\ell$ （非 解離アンモニアで0.067-0.121mg/l）で摂飭率が約 $60 \%$ に滅じ、増重率も約 $50 \%$ に低下する3)。同様に垔硝酸公 素についても、急性毒性は24h-LD $240760 \mathrm{mg} / \ell 、 96 \mathrm{~h}-$ LD 50 で205mg/ $\ell$ であり、慢性毒性は30mg/ $\ell$ で増重率が 約70\%に減じたと報告している4)。

また千葉はウナギを用い、飼育期間中 pHの低下時や アンモニアの堌加時に搷慨不良が多発することを報告し 
ている5)。これらは植物プランクトンの光合成活性と関 係があることを推測している。

止水式養魚において重要な地位を占める植物プランク トンの増殖をコントロールし、有効に活用することが必 要である。また水界環境の問題から下水処理の 3 次処理 に植物プランクトンを利用する研究もなされている6)。

本研究ては養魚池に扔ける藻類の役割を明らかにする 基硒研究の第一歩として止水式養魚池で周年見られる Scenedesmus acutusを用い高濃度の栄養塩類条件におけ る增殖特性について検討を加えた。

\section{2.実験材料および方法}

\section{2-1 供試藻類}

春季の養魚池水を平板寒天培地に叙布し、出現した コロニーを無菌水で希釈後、平板寒天培地に画線し、 これを数回繰り返し、単藻のScenedesmus acutusを分離 した。この藻は緑藻で 1 細胞の幅2.9-3.6 $\mu \mathrm{m}$ 、長さ9.5$10.7 \mu \mathrm{m}$ でった。実験には本単㩰株を液体培地で前培 盖し、対数增殖期の藻を蒸留水で 2 回洗浄して使用し た。

\section{2-2 培地および培美方法}

分離、前培養および本培養の基本培地としてGorham の培地を用いた（Table 1) 7)。培養は温度 25-30 0 、 24 時間連続照明の条件で行った。光源には白色蛍光灯を 用い、培養容器表面て3,000luxの照度を与えた。培養容 器は 500 と の振とう培養フラスコを用い、1 分間 60 往復 の水平往復振とうを行った。

\begin{tabular}{ll}
\multicolumn{2}{c}{ Table 1.Gorham's medium $(\mathrm{mg} / \ell)$} \\
\hline $\mathrm{NaNO}_{3}$ & $496(\mathrm{~N}=81.7)$ \\
$\mathrm{K}_{2} \mathrm{HPO}_{4}$ & $39(\mathrm{P}=6.9)$ \\
$\mathrm{MgSO}_{4} \cdot 7 \mathrm{H}_{2} \mathrm{O}$ & 75 \\
$\mathrm{CaCl}_{2} \cdot 2 \mathrm{H}_{2} \mathrm{O}$ & 36 \\
$\mathrm{Na}_{2} \mathrm{CO}_{3}$ & 20 \\
$\mathrm{Na}_{2} \mathrm{SiO}_{3}$ & 58 \\
$\mathrm{Fe}-\mathrm{citrate}$ & 6 \\
Citric acid & 6 \\
EDTA & 1 \\
\hline
\end{tabular}

\section{2-3 增殖贯の測定法}

島津製分光光度計UV-140-01 者用い、波長750nm、光 路長 $10 \mathrm{~mm}$ の吸光度を測定し、増殖量を求めた。またワ ットマンGFCを用い、乾燥重量を測定し、吸光度との関 係を調べた。

\section{3.結 果}

\section{3-1 增殖曲線}

$750 \mathrm{~nm}$ の吸光度と乾燥重量の関係を Fig.1に示した。吸 光度 0.8 以下では藻体量上比例関係が得られた。吸光度

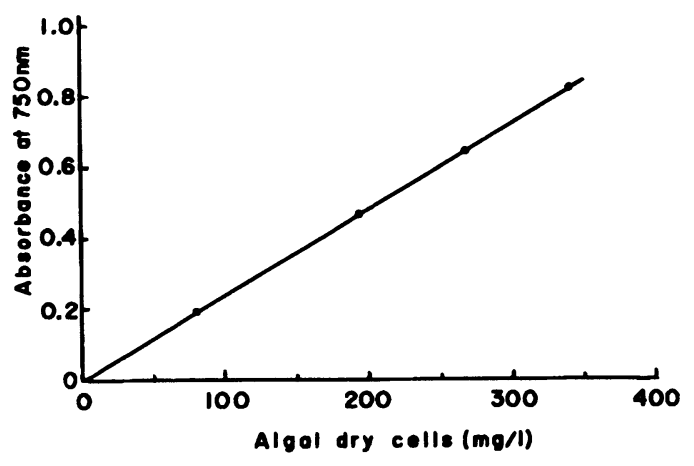

Fig. 1. Relation between absorbance (at $750 \mathrm{~nm}$ ) and dry weight of S. acutus.

の440倍が乾燥重量のmg/ $\ell$ に相当した。以後の実験て は吸光度による涤類の増殖量を表示した。

基本培地の增殖曲線をFig.2に示した。培養 5 日目ま では対数的な増殖が認められたが、5 日目以降、増殖速 度が俆々に低下する傾向が認められた。培養開始から 5 日目までの比增殖速度 $(\mu)$ を算出すると、0.53day ${ }^{-1}$ と なり、従って倍加時間は1.3日であった。培養14日目で 定常期に達したのて、培盖14日目の吸光度をもって . acutusの増殖量の比較を行った。

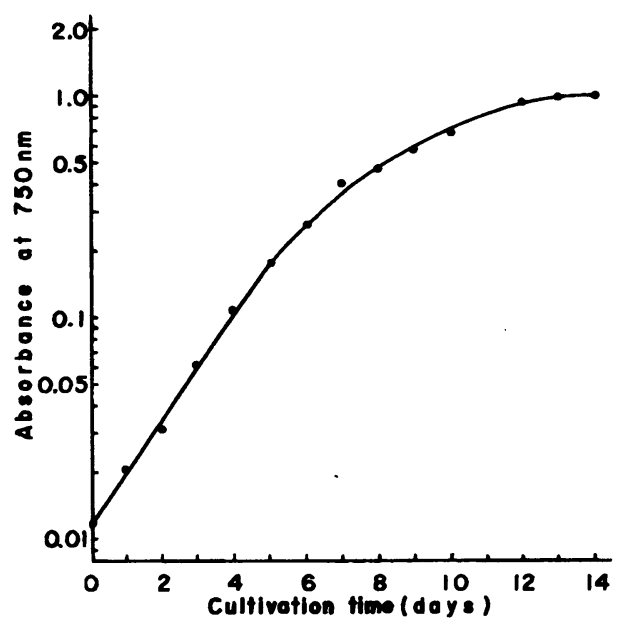

Fig. 2. Growth curve of $S$. acutus in Gorham's medium.

\section{3-2 pHの影䉕}

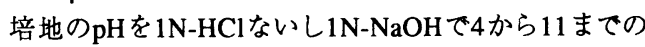
範囲に調整した基本培地抢よび基本培地の窒素源である $\mathrm{NaNO}_{3}$ を $\mathrm{NH}_{4} \mathrm{NO}_{3}$ に替えた培地（窒素量は等量）を用い て、增殖に及はす $\mathrm{pH}$ の影響を調べた。結果を Fig.3(a) と (b)に示した。 $\mathrm{NaNO}_{3}$ の場合、 $\mathrm{pH} 7$ の時に吸光度 1.3 と最 大を示し、 $\mu$ も同様に $\mathrm{pH} 7$ 7 $0.60 \mathrm{day}^{-1}$ と最大を示した。 $\mathrm{NH}_{4} \mathrm{NO}_{3}$ の場合、 $\mathrm{pH} 9$ で最大の吸光度を示したが、比増 

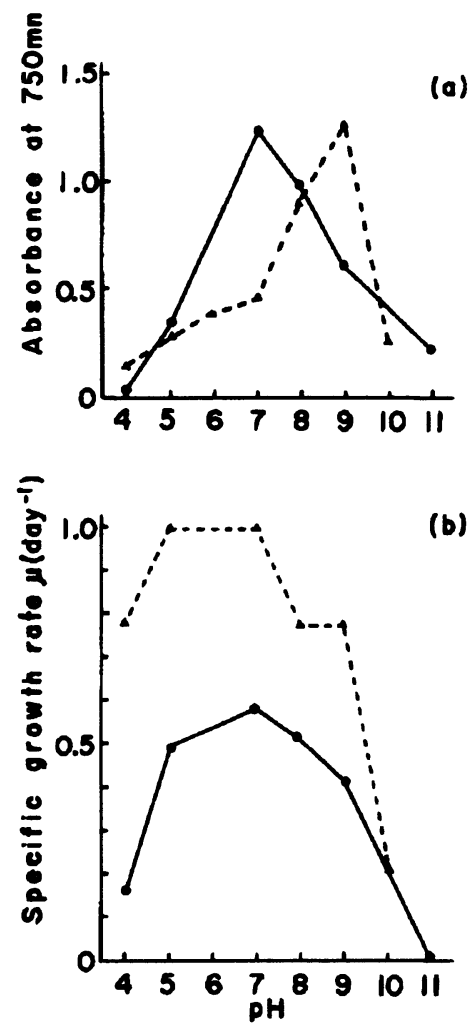

Fig. 3. Effect of initial $\mathrm{pH}$ on the growth of $S$. acutus. (a)absorbance at $750 \mathrm{~nm}$. (b)specific growth rate $(\mu)$. $\mathrm{NaNO}_{3}, \mathrm{~A}---\triangle \mathrm{NH}_{4} \mathrm{NO}_{3}$.

殖速度 $\mu$ はpH5-7で最大0.99 day ${ }^{-1}$ を示した。窒素源の種 類によって増殖に及ぼす $\mathrm{pH}$ が異なったが、以後の実験は $\mathrm{NaNO}_{3}$ を窒素源として用いたのでpH8に調整して行った。

\section{3-3 窒秦の影量}

窒素量を等量として、尿素、塩化アンモニウム、硝酸 アンモニウム、亜硝酸ナトリウムおよび硝酸ナトリウム を用いた培地での増殖量の影響を検討した。窒素量とし

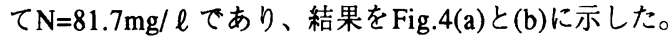
いずれの窒素源においても藻体量が吸光度で 0.7 以上と 良好な増殖を示した。11日目の増殖量は尿素の場合が 最大を示し、次いで塩化アンモニウム、硝酸ナトリウ ム、亜硝酸ナトリウム、硝酸アンモニウムの順であった。 比増殖速度は尿素が最も高く $\mu=0.77 \mathrm{day}^{-1}$ であり、一方 硝酸ナトリウムおよび垔硝酸ナトリウムがやや低い值を 示した。培地の $\mathrm{pH}$ は藻類の増殖に伴い尿素、硝酸ナト リウムおよび垔硝酸ナトリウムで上昇し、実験終了時に 尿素でpH9、硝酸ナトリウムと亜硝酸ナトリウムで $\mathrm{pH} 10$ となった。また塩化アンモニウムと硝酸アンモニウムは 6 日目以降急激に低下し、pH4となった。
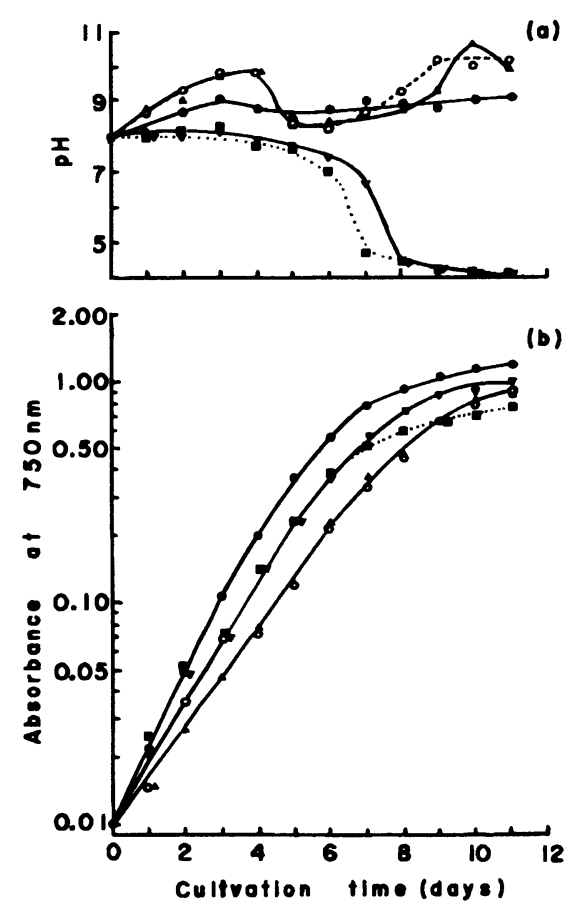

Fig. 4. Effect of nitrogen souce on the growth of $S$. acutus.

(a)change of $\mathrm{pH}$ in the media. (b)growth curve at $750 \mathrm{~nm}$. $-\mathrm{CO}\left(\mathrm{NH}_{2}\right)_{2}, \mathrm{O}----\mathrm{ONaNO}_{3}$,

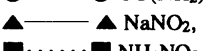

$\square \cdots \cdots \mathrm{NH}_{4} \mathrm{NO}_{3}, \nabla-\nabla \mathrm{NH}_{4} \mathrm{Cl}$.

養魚池で尿素形態の窒素は考えられないので、塩化ア ンモニウムおよび硝酸アンモニウムを用いて窒素濃度の 増殖量への影響を検討し、その結果をFig.5(a)に示した。 塩化アンモニウムの場合、窒素として 14 から $100 \mathrm{mg} / \ell$ の 範囲では吸光度 0.8 以上と良好な増殖を示したが、 $1,400 \mathrm{mg} / \ell$ では増殖が抑制された。硝酸アンモニウムの 場合、窒素が $28 \mathrm{mg} / \ell て ゙ 0.61$ と最大の增殖量を示した。 同様に比増殖速度 $\mu$ への影響をFig.5(b)に示した。塩化 アンモニウムの場合、窒素として $70 \mathrm{mg} / \ell$ が最大の $1.15 \mathrm{day}^{-1}$ を示し、硝酸アンモニウムの場合は $56 \mathrm{mg} / \ell$ 0.99 day $^{-1}$ と最大の $\mu$ を示した。

\section{3-4 リンの影䨐}

リン量の増殖量への影響を検討した結果をFig.6 (a)に 示した。塩化アンモニウムおよび硝酸アンモニウムいず れの場合も、リンとして $25 \mathrm{mg} / \ell$ 以上 $310 \mathrm{mg} / \ell$ までは吸 光度で 0.9 以上と良好な増殖を示し、 $3,100 \mathrm{mg} / \ell$ では増 殖が抑制された。比増殖速度 $\mu$ に対する影響をFig.6 (b) に示した。塩化アンモニウムの場合、リンとして $31 \mathrm{mg} / \ell$ て最大の $1.07 \mathrm{day}^{-1}$ を示し、硝酸アンモニウムの 場合、リンが6.2-62mg/ $\ell$ の範囲で高い $\mu$ を示した。 

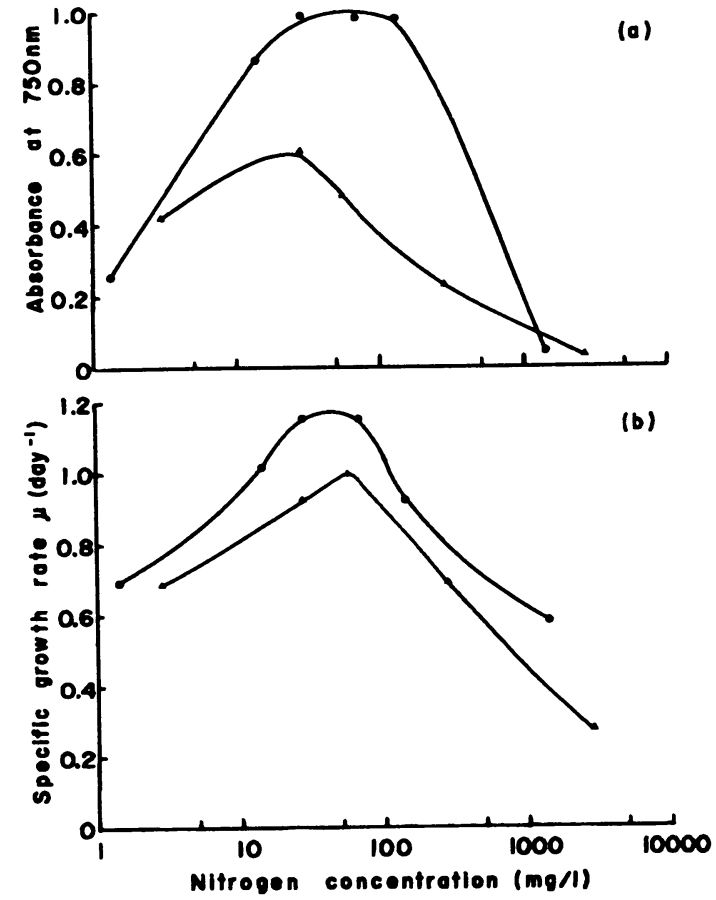

Fig. 5. Effect of $\mathrm{NH}_{4} \mathrm{Cl}$ and $\mathrm{NH}_{4} \mathrm{NO}_{3}$ concentration on the growth of $S$. acutus. (a) absorbance at $750 \mathrm{~nm}$ (b) specific growth rate $(\mu)$. $-\mathrm{NH}_{4} \mathrm{Cl}, \triangle-\mathrm{NH}_{4} \mathrm{NO}_{3}$.

\section{4.考 察}

養魚池で周年出現するS. acutusを単蕅培養し、各種の 環境因子および化学因子の増殖におよはす影響について 検討を加えた。S. acutusは緑藻で、750nmの吸光度と莯 体重量とは良好な相関がみとめられ、吸光度を測定する ことにより、落体重量を推定することが可能であっだ)。 RheeはScenedesmus sp.を用い、20 C、17,000lux $\mu$ が $0.59 \mathrm{day}^{-1}$ 9)、またRhee \& GothamはpH7.3-7.6、20 C以 上、 5,600 lux 以上て $\mu$ が $1.3 \mathrm{day}^{-1}$ で一定になると報告して いる10)。本実験の条件である3,000luxでは0.75 day ${ }^{-1}$ とな ク、この值よりも低い值であった。

$\mathrm{pH}$ と緑藻類の増殖との関係については、弱酸性から 弱アルカリ性でよく増殖することが知られている。 $S$. acutus もこの範囲で良好な增殖が認められたが、窒素化 合物の形態によって最大増殖量を示す培地の初期 $\mathrm{pH}$ 異なった。また培地の初期 $\mathrm{pH} よ る$ 比增殖速度 $\mu$ と最 大増殖量とは、必すしも一致しなかった。さらに 酸ナトリウムに比べ硝酸アンモニウムで高い值を示した。

窒素化合物の形態による最大增殖量への影鳘を調へ た。最大増殖量は尿素、塩化アンモニウム、硝酸ナトリ ウム、亜硝酸ナトリウム、硝酸アンモニウムの順であり、 いずれの窒素化合物でも良好な増殖を示した。培養中の
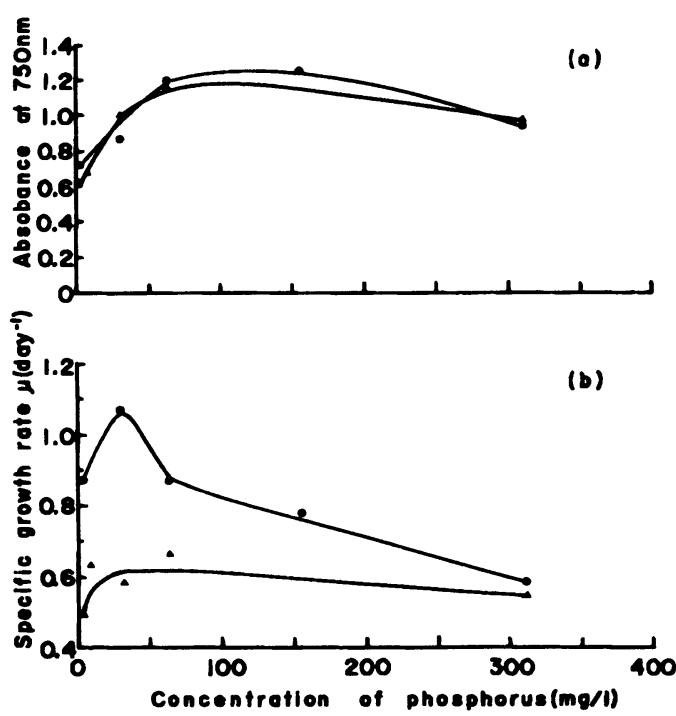

Fig. 6. Effect of phosphorus concentration on the growth of $S$. acutus. (a) absorbance at $750 \mathrm{~nm}$ (b) specific growth rate $(\mu)$. - $\mathrm{NH}_{4} \mathrm{Cl}$ as nitrogen souce, $\triangle-\triangle \mathrm{NH}_{4} \mathrm{NO}_{3}$ as nitrogen souce.

培地pHは、尿素、硝酸ナトリウム、亜硝酸ナトリウム で上昇し、塩化アンモニウム、硝酸アンモニウムで低下 した。アンモニウムを含む培地でpHが低下することは、 Trelease \& Trelease ${ }^{11)} 、$ Krauss \& Thomas ${ }^{12)}$ PMcLachlan \& Gorham $^{13)}$ 等が報告している。この実験で硝酸アンモニウ ムを用いた培地のpHが低下したことから、このS. acutus は硝酸イオンよりアンモニウムイオンを先に吸収したと 推測され、また尿素がそれ以上に吸収され易いと思われ $3^{14)}$ 。窒素の増殖に適した港度範囲は、Anabaena variabilis $^{14)}$ で 106-466mg/ $\ell$ や Phormidium luridum ${ }^{17}$ て 8-164m/ $\ell$ と比較してほほ同様な湦度範囲であった。Scenedesmus obliquus（日本淡水藻図鑑、内田老鶴戒新社(1977)では S.acutus）は6.2-7.5\%の窒素を含み、その $90 \%$ がタンパ ク質である12)ことから、増殖に多量の窒素を要求すると 考えられた。S. acutusは $\mathrm{NH}_{4}-\mathrm{N} 14 \mathrm{mg} / \ell$ の場合約 $330 \mathrm{mg} / \ell$ の莯体が増殖したことから、窒素の約24倍の落体が生成 されたことになり、Microsystisで30倍16)、Phormidumて 15倍17)の報告があり、再者の中間的な窒素要求性の株 であった。

良好な増殖が得られるリン乑度は $M$. aeruginosaて $0.18 \mathrm{mg} / \ell^{18)} 、 0.9 \mathrm{mg} / \ell^{15)} 、$ Anabaena spiroides $\tau 0.52 \mathrm{mg} / \ell^{19)}$ およびPhormidium persicinumで約 $1 \mathrm{mg} / \ell^{20)}$ と報告され またS. obliquusの緗胞内リン量が1.02-1.82\%含有されて 
いる ${ }^{12)}$ 。実験に供した $S$. acutusは $\mathrm{NH}_{4} \mathrm{NO}_{3}$ の場合、リン $62 \mathrm{mg} / \ell 、 \mathrm{NH}_{4} \mathrm{Cl}$ の場合、リン $155 \mathrm{mg} / \ell$ で最大の増殖量 が得られたが、 $\mathrm{NH}_{4} \mathrm{Cl}$ の場合、 $3.1 \mathrm{mg} / \ell$ のリンから $313 \mathrm{mg} / \ell$ の藻体が得られ、リンに対し100倍の藻体が生 成すると考えられた。このことからS. acutusはS. obliquusと 同様であり、藍藻類に比し高洪度のリンを要求する株と 考えられた。

\section{5.まとめ}

緑莯類S. acutusを養魚池から単藻培盖し、その栄養塩 の要求性を検討した。増殖には弱アルカリ性が適し、最 適pHは7-9であった。窒素源としては尿素、アンモニウ ム、亜硝酸および硝酸塩どれでも良く、窒素が $14 \mathrm{mg} / \ell$ 以上で良好な増殖が認められた。リンを高濃度に要求す る株であった。

\section{引用文献}

1) 千葉健治、ステファノ・マルトラーノ（1983）：水 質環境と魚類の成長 X. 水産增殖, 31、26-32.

2）平野䄈二郎（1980）：止水式盖魚（淡水養魚と用 水 日本水産学会編), 恒生社厚生閣（東京）, 4752.

3）山形陽一、丹羽誠（1982）：日本ウナギに対するア ンモニアの急性毒性および慢性毒性. 日本水産学会 誌, 48, 171-176.

4）山形陽一、丹羽誠（1979）：亜硝酸のウナギに対す る毒性について. 水産増殖, 27, 5-11.

5）千葉健治(1980): 水質環境と魚類の成長 VII. 水産増 殖. 28,66-77.

6) Talbot, P., J.-M. Thebault, A. Dauta and J, DE LA Noue (1991): A Comparative study and mathematical modeling of temperature, light and growth of three microalgae potentially useful for wastwater treatment. Wat. Res. 25, 465-4

7) Hughes, E. O., P. R. Gorham and U. A. Zehnder (1958): Toxicity of a unialgal culture of Microsystis aeruginosa. Can. J. Microbial., 4, 225-236.

8）保坂三継 (1991)：村山眝水池から分離した Anabaena macrospora MYK87Xの培養と增殖特性について.日本 水処理生物学会誌, 27, 21-31.

9) Rhee,G-Y. (1978) : Effects of N:P atomic ratios and nitrate limitation on algal growth, cell composition, and nitrate uptake. Limnol. Ocenogr., 23, 10-25.

10) Rhee,G-Y. and I.J.Gotham (1981) : The effect of environmental factors on phytoplankton growth : Temperature and the interactions of temperature with nutrient limitation. Limnol. Oceanogr., 26, 635-648.

11) Trelease, S. F. and H. M. Trelease (1935) : Changes in hydrogenion concentration of culture solutions containing nitrate and ammonium nitrogen. Amer. J. Bot., 22, 520-542.

12) Krauss, R. W. and W. H. Thomas (1954): The Growth and inorganic nutrition of Scenedesmus obliquus in mass cultere. Plant Physiol., 29, 250-214.

13) McLachlan, J. and P. R. Gorham (1961): Growth of Microcystis aeruginosa KUTZ. in a precipitate-free medium buffer with TRIS. Can. J. Microbiol., 7, 869-882.

14) Kratz, W. A. and J. Myers (1955) : Nutrition and growth of blue-green algae. Amer. J, Bot., 42, 282-287.

15) Zehnder, A. and P. R. Gorham (1960) : Facters influencing the growth of Microsystis aeruginosa KUTZ.emend.ELENKIN.,Can. J. Microbiol., 8, 1-11.

16) 矢木修身、萩原富司、高村義親、須藤隆一(1984)： 霞ヶ浦から分離したMicrocystisの無菌株と単藻株の 增殖特性. 水質污濁研究, 2. 496-503.

17) 小橋二夫、出口吉昭、東 禎三、矢崎仁也、矢木 修身(1991)：盖魚池から分離したPhormidum luridum の增殖特性. 日本水処理生物学会誌, 27, 11-17.

18) Gerloff, G. C., G. P. Fitzgerald and F. Skoog (1952) : The mineral nutrition of Microcystis aenuginosa. Amer. J. Bot., 39, 26-32.

19) Volk, S. L. and H. K. Phinney (1966) : Mineral requirement for the growth of Anabaena spiroides in vitro. Can. J. Bot., 46, 619-630.

20) Pinter, I. J. and L. Provasoli (1958) : Artifical cultivation of red-pigmented marine blue-green alga, Phormidium persicium. J. Gen. Microbiol., 18, 190-197. 